\title{
Genome-wide Scan for Serum Ghrelin Detects Linkage on Chromosome 1p36 in Hispanic Children: Results From the Viva La Familia Study
}

\author{
V. SAROJA VORUGANTI, HARALD H.H. GÖRING, VINCENT P. DIEGO, GUOWEN CAI, NITESH R. MEHTA, KARIN HAACK, \\ SHELLEY A. COLE, NANCY F. BUTTE, AND ANTHONY G. COMUZZIE
}

\begin{abstract}
Department of Genetics [V.S.V., H.H.H.G., V.P.D., K.H., S.A.C., A.G.C.], Southwest Foundation for Biomedical Research, San Antonio, Texas 78227; Department of Pediatrics [G.C., N.R.M., N.F.B.], USDA/ARS Children's Nutrition Research Center, Baylor College of Medicine, Houston, Texas 77030
\end{abstract}

\begin{abstract}
This study was conducted to investigate genetic influence on serum ghrelin and its relationship with adiposity-related phenotypes in Hispanic children $(n=1030)$ from the Viva La Familia study (VFS). Anthropometric measurements and levels of serum ghrelin were estimated and genetic analyses conducted according to standard procedures. Mean age, body mass index (BMI), and serum ghrelin were $11 \pm 0.13 \mathrm{y}, 25 \pm 0.24 \mathrm{~kg} / \mathrm{m}^{2}$ and $38 \pm 0.5$ $\mathrm{ng} / \mathrm{mL}$, respectively. Significant heritabilities $(p<0.001)$ were obtained for BMI, weight, fat mass, percent fat, waist circumference, waist-to-height ratio, and ghrelin. Bivariate analyses of ghrelin with adiposity traits showed significant negative genetic correlations $(p<$ 0.0001 ) with weight, BMI, fat mass, percent fat, waist circumference, and waist-to-height ratio. A genome-wide scan for ghrelin detected significant linkage on chromosome 1p36.2 between STR markers D1S2697 and D1S199 (LOD = 3.2). The same region on chromosome 1 was the site of linkage for insulin ( $\mathrm{LOD}=3.3$ ), insulinlike growth factor binding protein 1 (IGFBP1) $(\mathrm{LOD}=3.4$ ), homeostatic model assessment method (HOMA) (LOD $=2.9$ ), and C-peptide $(\mathrm{LOD}=2.0)$. Several family-based studies have reported linkages for obesity-related phenotypes in the region of $1 \mathrm{p} 36$. These results indicate the importance of this region in relation to adiposity in children from the VFS. (Pediatr Res 62: 445-450, 2007)
\end{abstract}

$\mathrm{O}^{\mathrm{b}}$ besity among children and adolescents is of great concern because accompanying adverse health consequences usually persist into adulthood. In the United States (US), there has been steady increase in past $20 \mathrm{y}$ in the number of children who are overweight. The proportion of children in age group $6-18$ y who are overweight increased from 6\% in 1976-1980 to $16 \%$ in 1999-2002 (1). These data reflect changing patterns in diet and lifestyle. A decrease in physical activity and shift in diet toward high-fat foods among children may be some of the contributing factors to obesity (2). In addition, disruption in energy balance (energy intake and expenditure or relevant

Received January 11, 2007; accepted May 19, 2007.

Correspondence: V. Saroja Voruganti, Ph.D., Department of Genetics, Southwest Foundation for Biomedical Research, P.O. Box 760549, San Antonio, TX 78245-0549; e-mail: svorugan@sfbrgenetics.org

This project was funded with federal funds from the NIH R01. DK59264, USDA/ARS under Cooperative Agreement 58-6250-51000-037 and MH59490 from NIH. This investigation was conducted in a facility constructed with support from Research Facilities. Improvement Program Grant Number 1 C06 RR13556-01 from the National Center for Research. Resources supported by the NIH. metabolic pathways) can also result in obesity in both children and adults (3).

A key player in the regulation of energy homeostasis is the central nervous system (CNS), which controls food intake with the help of information received from distinct metabolic, hormonal, and neural signals (4). Ghrelin, a gastrointestinal hormone, is one such signal that is secreted by X/A-like cells in the fundus portion of the stomach and acts through its receptors situated on neurons in the arcuate nucleus of the hypothalamus (5). Circulating levels of ghrelin are at their highest before a meal and drop to their lowest after a meal (6), making it a possible signal for a low-energy state (7).

Several human and animal studies have shown circulating ghrelin to be inversely related to body weight, BMI, waist circumference, serum insulin, and insulin resistance $(8,9)$. Similar results have been reported in studies conducted with children $(10,11)$. However, few studies have shown the genetic influence on circulating ghrelin, particularly in children. A small number of studies have identified genetic variants in the ghrelin gene in children. The effects of these variants on energy balance or weight regulation are, however, not yet clear as these studies have produced contradictory results $(12,13)$. Therefore, this study was conducted to estimate the genetic influence on serum ghrelin and to investigate the genetic correlations between ghrelin and other obesity-related phenotypes in Hispanic children.

\section{METHODS}

Study design. Data for this study were obtained from children participating in the VFS (14). Participants $(n=1030)$ in this study were taken from 319 Hispanic families residing in and around Houston, TX. The VFS was designed to characterize and identify genes influencing variation in obesityrelated phenotypes in Hispanic children. To participate in this study, a proband was required to be overweight ( $>95$ percentile for BMI and $>85$ percentile for fat mass) and between ages 4 and $19 \mathrm{y}$. In addition, only those families who had three or more children in the age group 4-19 y were recruited. Information regarding pedigree structure, sociodemographics, and anthropometrics was obtained. All participants underwent physical examination, and blood samples were taken after a 12-h overnight fast. Serum was extracted and stored in aliquots at $-80^{\circ} \mathrm{C}$ for clinical chemistries and endo-

Abbreviations: HOMA, homeostatic model assessment method; IGFBP1, insulinlike growth factor binding protein 1; IGFBP3, insulin-like growth factor binding protein 3; QTL, quantitative trait locus 
crine assays. Genotyping was conducted with DNA derived from lymphocytes. Informed consent was obtained from all participants in this study, which was approved by the Institutional Review Board for Human Subject Research for Baylor College of Medicine and Affiliated Hospitals and for the Southwest Foundation for Biomedical Research.

Phenotyping. Anthropometric measurements included height, weight, waist circumference, and BMI. Weight for the children was measured twice by a trained nurse using a Healthometer electronic scale (Bridgeview, IL). Standing height was measured twice to the nearest $0.1 \mathrm{~cm}$ using a SECA wall-mounted stadiometer (Holtain Limited, Crymych, UK). The waist circumference was measured twice, in millimeters, midway between the inferior border of the rib cage and the superior border of the iliac crest. The hip circumference was also measured twice, in millimeters, at the level of the trochanter. The average of the two measurements for each variable was then used in the analyses. BMI was calculated by dividing weight (kilograms) by height (meters squared). Children with BMI $>95$ percentile (15) and fat mass $>85$ th percentile (16) were considered overweight. Body composition (fat mass and fat-free mass) was estimated by dual-energy x-ray absorptiometry (DEXA) using a Hologic Delphi A whole-body scanner (Delphi A, Hologic Inc., Waltham, MA). Commercial radioimmunoassay (RIA) kits were used to measure fasting serum insulin and leptin (Linco Research Inc., St. Charles, MO) and total ghrelin (Phoenix Pharmaceuticals Inc., Belmont, CA). Free and bound IGF1 and IGF binding proteins 1 and 3 (IGFBP1, IGFBP3) were determined using enzyme-linked immunosorbent assay (ELISA) kits (Diagnostic Systems Laboratory, Webster, TX). Fasting glucose was measured by enzymatic-colorimetric techniques using the GM7 analyzer (Analox Instruments, Lunenburg, MA) and Microquant Platereader (Biotek Instruments, Winooski, VT). Homeostatic model assessment method (HOMA) was used to estimate insulin resistance (17), which is computed as HOMA $=$ [serum insulin $(\mathrm{mU} / \mathrm{mL}) *$ serum glucose $(\mathrm{mmol} / \mathrm{L})] / 22.5$.

Genotyping. DNA was prepared from $10 \mathrm{~mL}$ whole blood using a Genomic DNA purification kit (Promega, Madison, WI). All participants were genotyped for short tandem repeats (STRs) that were spaced at an average interval of $10 \mathrm{cM}$ (range, 2.4-24.1). Autosomal markers from the ABI PRISM Linkage Mapping Set-MD-10 version 2.5 (Applied Biosystems, Foster City, CA) were used. Each marker was amplified in a separate polymerase chain reaction (PCR) using fluorescently labeled primers and then the PCR product was pooled with others using Robbins Hydra-384 microdispenser, where a standard was added to each pool. The STRs were quantified by fluorescent emissions by comparison with the standard and the scoring of genotypes was performed using the Genotyper software package (Applied Biosystems).

Pedigree and mendelian errors were detected using software PREST (pedigree relationship statistical tests) (18) and SIMWALK2 (19), respectively. Multipoint identity-by-descent matrices for genome-wide linkage analyses were calculated using a linkage analysis package (LOKI) (20). The chromosomal map used in these computations was developed based on marker locations reported by DeCode genetics (21).

Statistical analyses. Variance components decomposition method was used to estimate heritability and identify the chromosomal location(s) affecting variation in serum ghrelin levels. This method is implemented in software program sequential oligogenic linkage analysis routines (SOLAR) (22). To estimate the genetic component in the variation of serum ghrelin, first its heritability was estimated. To find a putative quantitative trait locus (QTL) or loci (QTLs) that might be affecting the serum levels of ghrelin, a multipoint linkage analysis was conducted. This method has been described in detail elsewhere (22-24). In short, this analysis is an extension of the variance components approach in which a QTL component is added to the basic model. The phenotypic correlations between family members can be modeled as the cumulative effect of identity by descent (IBD) shared by family members at a specific QTL associated with a marker, residual genetic and environmental effects.

In addition, a variance components approach, implemented in SOLAR, was used to estimate genetic correlations between serum ghrelin and other traits (25). The phenotypic correlation between serum ghrelin and other traits can be explained in terms of its genetic and environmental correlation components.

$$
\rho_{p}=\rho_{g}\left[\sqrt{h_{1}^{2}} \sqrt{h_{2}^{2}}\right]+\rho_{e}\left[\sqrt{\left(1-h_{1}^{2}\right)} \sqrt{\left(1-h_{2}^{2}\right)}\right] ;
$$

$h_{1}^{2}$ and $h_{2}^{2}$ are the heritabilities of the two phenotypes being studied, and $\rho$ ${ }_{G}$ and $\rho_{E}$ are the additive genetic and environmental correlations between the traits, respectively.

A variance components approach for modeling a bivariate trait was used to estimate genetic correlations between serum ghrelin and other traits. A bivariate trait is simply one that is composed of two constituent traits that are assumed to be jointly multivariately normal in distribution. Thus, the bivariate variance components model can be thought of as a model that incorporates what would be the regular variance components model per constituent trait of the overall bivariate trait and a component for the covariance between the constituent traits. The covariance between constituent traits can be reparameterized as a product of the constituent trait SDs and their correlation (25-27).

A model in which all the parameters are estimated is compared with a model in which the genetic correlation is constrained to zero. This is known as a likelihood ratio test (LRT), and the resultant LRT statistic in this particular case was distributed asymptotically as a $1 / 2: 1 / 2$ mixture of a $\chi^{2}$ variable with $1 \mathrm{df}$ and a point mass at zero (28). If the result of this statistical test is significant, then we infer that the traits share effects of a common set of genes.

The extent of shared genetic effects is verified by a second statistical test that compares the model in which all the parameters are estimated with one in which the genetic correlation is constrained to one. The basic premise of this model is that if the genetic correlation equals 1 , then it can be said that genes controlling expression of two traits completely overlap with each other. However, if the genetic correlation is significantly different from 1 , then the extent to which there is overlap is given by the estimate of the genetic correlation coefficient. Thus, the null hypothesis states that there is complete pleiotropy, whereas the alternative hypothesis states that there is incomplete pleiotropy in which the overlap of shared genes is not complete.

\section{RESULTS}

The total number of children participating in this study was 1030 (boys $=510$, girls $=520$ ). A detailed description of the numbers of relative pairs in this sample is given in Table 1. The mean age and BMI were $11 \pm 0.13 \mathrm{y}$ (range, 4-19) and $25 \pm 0.24 \mathrm{~kg} / \mathrm{m}^{2}$ (range, 13-62), respectively. Their descriptive statistics are depicted in Table 2. Mean \pm SEM ghrelin concentrations were $38 \pm 0.5 \mathrm{ng} / \mathrm{mL}$ (range, $6-127 \mathrm{ng} / \mathrm{mL}$ ), with no significant differences between boys and girls.

For heritability and linkage analysis of serum ghrelin, age, age $^{2}$, sex, and the interaction between age, age ${ }^{2}$ and sex were used as covariates. Heritability for serum ghrelin was $0.61 \pm$ 0.08. Table 2 and Table 3 display heritabilities of other adiposity-related traits measured and bivariate correlations between serum ghrelin and adiposity-related phenotypes, respectively. Significant genetic correlations $\left(\rho_{\mathrm{G}}\right)(p<0.001)$ were demonstrated between ghrelin and weight $(-0.48)$, BMI $(-0.53)$, percent fat $(-0.45)$, fat mass $(-0.50)$, waist circumference $(-0.54)$, and waist-to-height ratio $(-0.52)$. Significant genetic correlations $\left(\rho_{\mathrm{G}}\right)(p<0.01)$ were also found between ghrelin and insulin $(-0.40)$, C-peptide $(-0.43)$, HOMA (-0.40), IGFBP1 (-0.44), and IGFBP3 (0.15).

Figure 1 depicts the genome-wide scan LOD score plot obtained in linkage analyses for serum ghrelin. The highest multipoint LOD score of 3.2 ( $p=0.00006$ ) was found between STR markers D1S2697 and D1S199 on the terminal end of the short arm of chromosome 1 on p36.2 (Fig. 2). The 1-LOD support interval spans about $20 \mathrm{cM}(20-40 \mathrm{cM})$ on chromosome 1. Genome scan for serum ghrelin also revealed

Table 1. Relative pairs used in this analysis

\begin{tabular}{lc}
\hline \multicolumn{1}{c}{ Relationship } & No. of pairs \\
\hline Siblings & 845 \\
Half-siblings & 150 \\
First cousins & 333 \\
Half first cousins & 6 \\
Double first cousins & 1 \\
Half siblings and first cousins & 2 \\
Identical sib pair & 2 \\
Total & 1339 \\
\hline
\end{tabular}


Table 2. Heritabilities $\left(h^{2}\right)$ of adiposity-related traits and their serum biochemistries

\begin{tabular}{lccc}
\hline \multicolumn{1}{c}{ Phenotype* } & Mean $($ SEM $)$ & $\mathrm{h}^{2}(\mathrm{SEM})$ & $p$ \\
\hline Ghrelin $(\mathrm{ng} / \mathrm{mL})$ & $38.0(0.5)$ & $0.61(0.08)$ & $<0.00001$ \\
Weight $(\mathrm{kg})$ & $54.41(0.86)$ & $0.31(0.08)$ & $<0.0001$ \\
BMI $\left(\mathrm{kg} / \mathrm{m}^{2}\right)$ & $25.10(0.24)$ & $0.32(0.08)$ & $<0.0001$ \\
Fat $(\%)$ & $0.33(0.002)$ & $0.35(0.08)$ & $<0.0001$ \\
Fat mass $(\mathrm{g})$ & $18.94(0.39)$ & $0.27(0.08)$ & $<0.0001$ \\
Waist circumference $(\mathrm{cm})$ & $75.61(0.56)$ & $0.41(0.07)$ & $<0.0001$ \\
Waist-to-height ratio & $0.53(0.002)$ & $0.41(0.07)$ & $<0.0001$ \\
Leptin & $0.17(14.9)$ & $0.25(0.07)$ & $<0.001$ \\
Insulin $(\mu \mathrm{IU} / \mathrm{mL})$ & $22.50(0.60)$ & $0.19(0.06)$ & $<0.001$ \\
C-peptide $(\mathrm{ng} / \mathrm{mL})$ & $2.68(0.05)$ & $0.56(0.07)$ & $<0.0001$ \\
HOMA & $5.28(0.16)$ & $0.19(0.06)$ & $<0.001$ \\
IGF1(free) $(\mathrm{ng} / \mathrm{mL})$ & $0.81(0.002)$ & $0.63(0.08)$ & $<0.0001$ \\
IGF1 (bound) $(\mathrm{ng} / \mathrm{mL})$ & $348.84(6.23)$ & $0.56(0.08)$ & $<0.0001$ \\
IGFBP1 $(\mathrm{ng} / \mathrm{mL})$ & $24.66(0.86)$ & $0.18(0.08)$ & $<0.001$ \\
IGFBP3 $(\mathrm{ng} / \mathrm{mL})$ & $3532.95(43.48)$ & $0.93(0.08)$ & $<0.00001$ \\
\hline
\end{tabular}

* All phenotypes were log transformed.

locations on chromosomes 2, 4, 5, 6, and 7 with a LOD score $>1$ but did not show evidence of suggestive or significant linkage. The region on chromosome $1(36-39 \mathrm{cM})$ also yielded significant linkages for insulin at $38 \mathrm{cM}(\mathrm{LOD}=3.3$, $p=0.00005)$ and IGFBP1 at $39 \mathrm{cM}(\mathrm{LOD}=3.4, p=$ 0.00004 ), and C-peptide (LOD = 2.0) and HOMA (LOD = 2.9) showed evidence of suggestive linkage at $38 \mathrm{cM}$ (Fig. 3) on chromosome 1 . However, other adiposity measures such as weight $(\mathrm{LOD}=1.7)$, waist-to-height ratio $(\mathrm{LOD}=1.5)$, BMI $(\mathrm{LOD}=1.3)$, fat mass $(\mathrm{LOD}=0.9)$, and waist circumference $(\mathrm{LOD}=0.5)$ did not show evidence of linkage to $1 \mathrm{p} 36.2$.

\section{DISCUSSION}

This study was aimed at investigating the genetic influence on the variation in serum ghrelin in children and adolescents. Given the problem of obesity in the US, particularly in children, understanding the influence of genes on the regulation of energy is essential. One of the hormones that play a major role in energy intake is ghrelin. Here, we demonstrate a substantial genetic component in the variation in serum ghre-

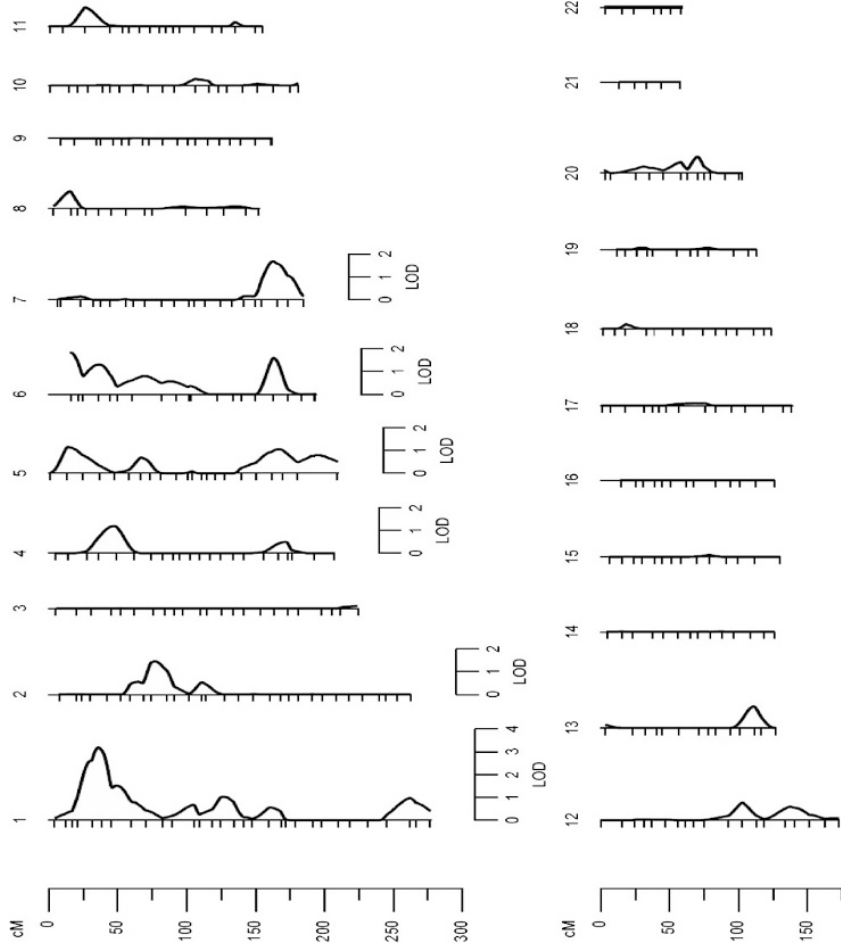

Figure 1. String plot of fasting serum ghrelin (markers are depicted on $x$ axis and LOD scores on $y$ axis).

lin and evidence of a strong linkage signal for serum ghrelin in the region of $1 \mathrm{p} 36$. Identification of a QTL influencing variation in serum ghrelin in this region is promising as this region encodes obesity-related candidate genes such as tumor necrosis factor $\alpha$ receptor 2 (TNFR2), also known as tumor necrosis factor receptor subfamily, member $1 \mathrm{~B}$ (TNFRSF1B) (29) and mitofusin 2 (MFN2) (30). Flanking to the left side of our 1-LOD support interval is the mammalian target of rapamycin (mTOR) gene, an important player in energy regulation (31).

The TNFR2 gene encodes for the main TNF receptor that is found on circulating $\mathrm{T}$ cells. This receptor seems to be a major mediator of autoregulatory apoptosis in $\mathrm{CD}^{+}$cells (29).

Table 3. Genetic and phenotypic correlations of ghrelin with other adiposity-related traits

\begin{tabular}{|c|c|c|c|c|c|}
\hline Phenotype & $\rho_{\mathrm{G}}$ & $p\left(\rho_{\mathrm{G}}=0\right)$ & $p\left(\rho_{\mathrm{G}}=1\right)$ & $\begin{array}{l}\rho_{\mathrm{P}}\left(\text { calculated from } \rho_{\mathrm{G}}\right. \\
\left.\text { and } \rho_{\mathrm{E}}\right)\end{array}$ & $p$ \\
\hline Weight $(\mathrm{kg})$ & -0.48 & $<0.001$ & $<0.00001$ & -0.26 & $8.8 \times 10^{-56}$ \\
\hline $\mathrm{BMI}^{*}\left(\mathrm{~kg} / \mathrm{m}^{2}\right)$ & -0.53 & $<0.00001$ & $<0.001$ & -0.29 & $4.3 \times 10^{-58}$ \\
\hline Fat mass $(\mathrm{g})$ & -0.50 & $<0.0001$ & $<0.001$ & -0.26 & $2.9 \times 10^{-52}$ \\
\hline Waist circumference $(\mathrm{cm})$ & -0.54 & $<0.00001$ & $<0.0001$ & -0.31 & $7.7 \times 10^{-60}$ \\
\hline Waist-to-height ratio & -0.52 & $<0.0001$ & $<0.001$ & -0.30 & $1.9 \times 10^{-52}$ \\
\hline C-peptide (ng/mL) & -0.43 & $<0.001$ & $<0.001$ & -0.28 & $5.0 \times 10^{-52}$ \\
\hline HOMA & -0.40 & $<0.001$ & $<0.0001$ & -0.22 & $6.3 \times 10^{-52}$ \\
\hline IGF1(free) (ng/mL) & 0.13 & NS & NS & 0.08 & NS \\
\hline IGF1 (bound) (ng/mL) & 0.09 & NS & NS & 0.05 & NS \\
\hline IGFBP1 (ng/mL) & -0.44 & $<0.001$ & $<0.001$ & -0.21 & $1.7 \times 10^{-41}$ \\
\hline IGFBP3 (ng/mL) & 0.15 & $<0.01$ & $<0.00001$ & 0.11 & $2 \times 10^{-4}$ \\
\hline
\end{tabular}

NS, not significant.

$* \rho_{\mathrm{P}}$, phenotypic correlations; $\rho_{\mathrm{G}}$, genetic correlations; $\rho_{\mathrm{E}}$, environmental correlations. 


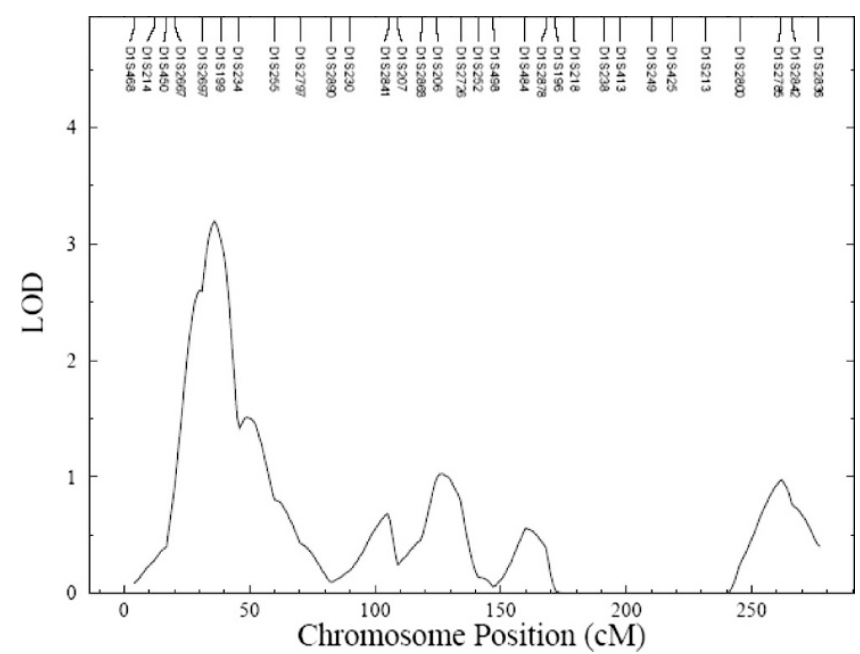

Figure 2. Multipoint LOD plot showing linkage of fasting serum ghrelin on chromosome 1 (markers are depicted on $x$ axis and LOD scores on $y$ axis).

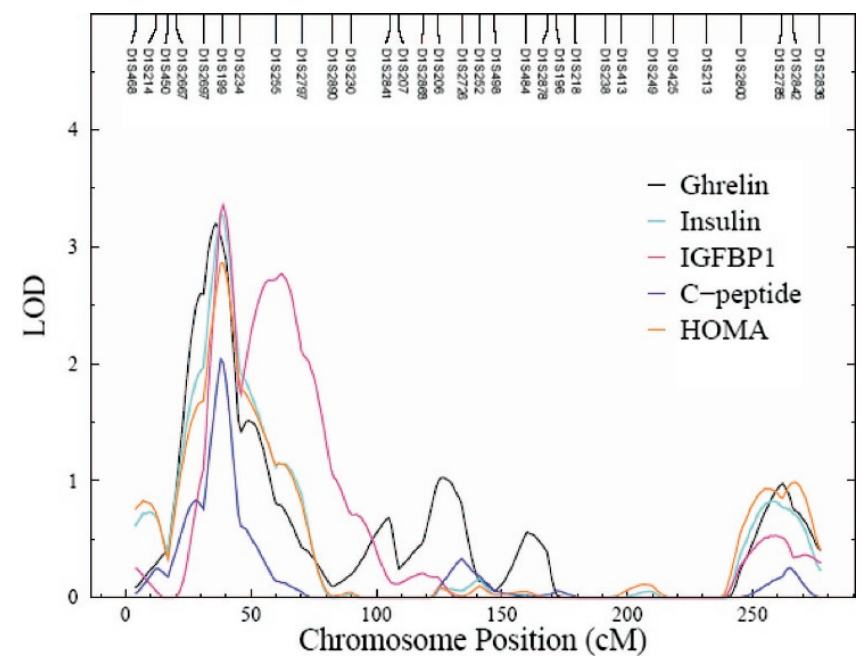

Figure 3. Multipoint LOD plot showing linkage of fasting serum ghrelin, insulin, C-peptide, IGFBP1, and HOMA on chromosome 1 (markers are depicted on $x$ axis and LOD scores on $y$ axis).

Polymorphisms in TNFR2 have been associated with obesity and insulin resistance (32). Mitofusins, particularly MFN2, are known to mediate the fusion of mitochondria and thereby maintain a balance in mitochondrion morphology. Bach et al. (33) found that obesity was associated with reduced MFN2 expression in both rats and humans. The mTOR protein, a serine-threonine kinase, acts as a fuel sensor in the regulation of protein synthesis and cell growth. Changes in body energy are synergistically modulated with changes in mTOR signaling, with lower energy stores enhancing mTOR signaling and vice versa (34). In this study, in addition to ghrelin, significant linkages for serum insulin and IGFBP1 and suggestive linkages for HOMA and C-peptide were found in the same chromosomal region.

The chromosomal region $1 \mathrm{p} 36$ has also been associated with obesity-related traits in previously reported linkage studies. Both Deng et al. (35) and their follow-up study (36) found variation in BMI to be linked to a locus on 1p36. A study conducted to examine the gene profiling of human visceral adipose tissue found the chromosomal region $1 \mathrm{p} 36.2-1 \mathrm{p} 36.3$ to be associated with this tissue (37). In another study of Mexican-Americans, Cai et al. (38) found linkage for body size-adiposity factor in this region of 1p36.2. Similarly, Pausava et al. (39) found that this region was associated with obesity and obesity-associated hypertension in a French-Canadian population, strengthening the possibility of this region regulating several obesity-related traits. In a study conducted by Gorlova et al. (40), evidence of linkage for BMI was found in this region of $1 \mathrm{p} 36$ in children and young adults.

To explore the relationship of ghrelin with insulin, leptin, and other adiposity-related measures, we conducted bivariate analyses. A significant genetic correlation $\left(\rho_{\mathrm{G}}\right)$ implies that the two traits share common genetics effects. Two hypotheses were tested in this study; one that stated that there were no shared genetic effects between the two given traits $\left(\rho_{\mathrm{G}}=0\right)$ and the other that there was a complete overlap of the genes that control the expression of the two given traits $\left(\rho_{\mathrm{G}}=1\right)$. Both hypotheses were rejected for all traits, except IGF1. This means that ghrelin shares common genetic effects with other adiposity-related traits but is in incomplete pleiotropy (same set of genes controlling the expression of both traits) with these traits.

To the best of our knowledge, no studies have looked at the genetic correlations between these phenotypes in children. Therefore, we estimated genetic as well as overall phenotypic correlations between these phenotypes. Negative correlations between ghrelin and adiposity-related phenotypes shown in this study have been reported earlier by other studies in children. Serum ghrelin levels have been inversely related to BMI, weight, percentage of body fat, waist circumference, waist-to-hip ratio, and insulin concentrations in normal weight children (12,41-44). We found negative correlations between ghrelin and HOMA, which supports the concept of low ghrelin levels in insulin resistance. The same finding was reported earlier in a study conducted in obese children and adolescents (10). Similarly, a significant negative correlation was observed between ghrelin and leptin, which has earlier been reported in children (11) and adults (45). However, other studies involving obese children (10) and children with Prader-Willi syndrome (41) did not show significant correlation between these two traits.

In addition, we examined the relationship between ghrelin and IGF1 (free and bound), IGFBP1, and IGFBP3. IGF1 is a polypeptide that is involved in several biochemical pathways related to cell growth, development, and insulin and glucose metabolism $(46,47)$. Circulating IGF1 is bound to their binding proteins IGFBPs, of which $90 \%$ of the IGF1 is bound by IGFBP3 (48). Besides carrying circulating IGFs, IGFBPs play an important role in regulating IGF's interaction with its receptors (48). Whatmore et al. (42) found positive correlation of ghrelin with IGFBP1 and negative with IGFBP3. Similar results were reported by Bacha and Arslanian (43). However, we found negative correlation between ghrelin and IGFBP1 and positive correlation between ghrelin and IGFBP3. This difference may be attributed to the fact that these studies were 
conducted in normal weight children, whereas our study included normal and overweight children. We found no significant association between IGF1 and ghrelin. Previously, studies in children have shown negative association between ghrelin and IGF1 $(42,49)$. However, studies in adults have shown conflicting reports with no significant relationship between ghrelin and IGF1 $(50,51)$, a positive correlation between the two (52), and a negative correlation between the two (52). This disparity may be due to the effect of obesity and insulin resistance on the relationship between ghrelin and IGF1 (53).

In summary, we found significant genetic influence on the variation in serum ghrelin in Hispanic children and a strong linkage signal on chromosome $1 \mathrm{p} 36$ that is affecting this variation. The region of chromosome $1 \mathrm{p} 36$ coincides with the location of obesity-related candidate genes and thus seems to be an important region in relation to energy homeostasis and adiposity.

Acknowledgments. The authors thank the families who participated in this study.

\section{REFERENCES}

1. Federal Interagency Forum on Child and Family Statistics 2005 America's Children: Key National Indicators of Well-Being. Available at: http://childstats.gov/ amchildren05/index.asp (accessed May 18, 2007)

2. Eaton DK, Kann L, Kinchen S, Ross J, Hawkins J, Harris WA, Lowry R, McManus T, Chyen D, Shanklin S, Lim C, Grunbaum JA, Wechsler H 2006 Youth risk behavior surveillance-United States, 2005. MMWR Surveill Summ 55:1-108

3. Broberger C 2005 Brain regulation of food intake and appetite: molecules and networks. J Intern Med 258:301-327

4. Strader AD, Woods SC 2005 Gastrointestinal hormones and food intake. Gastroenterology 128:175-191

5. Cowley MA, Grove KL 2004 Ghrelin-satisfying a hunger for the mechanism. Endocrinology 145:2604-2606

6. Cummings DE, Purnell JQ, Frayo RS, Schmidova K, Wisse BE, Weigle DS 2001 A preprandial rise in plasma ghrelin levels suggests a role in meal initiation in humans. Diabetes 50:1714-1718

7. Dallman MF 2003 Filling the interstices: ghrelin neurons plug several holes in the regulation of energy balance. Neuron 37:550-552

8. Purnell JQ, Weigle DS, Breen P, Cummings DE 2003 Ghrelin levels correlate with insulin levels, insulin resistance and high-density lipoprotein cholesterol, but not with gender, menopausal status or cortisol levels in humans. J Clin Endocrinol Metab 88:5747-5752

9. Holdstock C, Engstrom BE, Ohrvall M, Lind L, Sundbom M, Karlson A 2003 Ghrelin and adipose tissue regulatory peptides: effect of gastric bypass surgery in obese humans. J Clin Endocrinol Metab 88:3177-3183

10. Ikezaki A, Hosoda H, Ito K, Iwama N, Miura N, Matsuoka H, Kondo C, Kojima M, Kangawa K, Sugihara S 2002 Fasting plasma ghrelin levels are negatively correlated with insulin resistance and PAI-1, but not with leptin, in obese children and adolescents. Diabetes 51:3408-3411

11. Park HS, Lee KU, Kim YS, Park CY 2005 Relationships between fasting plasma ghrelin levels and metabolic parameters in children and adolescents. Metabolism 54:925-929

12. Vivenza D, Rapa A, Castellino N, Bellone S, Petri A, Vacca G, Aimaretti G, Broglio F, Bona G 2004 Ghrelin gene polymorphisms and ghrelin, insulin, IGF-1, leptin and anthropometric data in children and adolescents. Eur J Endocrinol 151:127-133

13. Miraglia del Giudice E, Santoro N, Cirillo G, Raimondo P, Grandone A, D'Aniello A, Di Nardo M, Perrone L 2004 Molecular screening of the ghrelin gene in Italian obese children: the Leu72Met variant is associated with an earlier onset of obesity. Int J Obes Relat Metab Disord 28:447-450

14. Butte NF, Cai G, Cole SA, Comuzzie AG 2006 Viva La Familia Study: genetic and environmental contributions to childhood obesity and its comorbidities in the Hispanic populations. Am J Clin Nutr 84:646-654

15. Kuczmarski RJ, Ogden CL, Grummer-Strawn LM 2000 CDC growth charts: United States. Adv Data 314:1-27

16. Ellis KJ 1997 Body composition of a young multiethnic male population. Am J Clin Nutr 66:1323-1331

17. Matthews DR, Hosker JP, Rudensky AS, Naylor BA, Treacher DF, Turner RC 1985 Homeostasis model assessment: insulin resistance and beta cell function from fasting glucose and insulin concentrations in man. Diabetologia 28:412-419
18. Sun L, Wilder K, McPeek MS 2002 Enhanced pedigree error detection. Hum Hered 54:99-110

19. Sobel E, Lange K 1996 Descent graphs in pedigree analysis: applications to haplotyping, location scores, and marker sharing statistics. Am J Hum Genet 58:1323-1337

20. Heath SC 1997 Markov chain Monte Carlo segregation and linkage analysis for oligogenic models. Am J Hum Genet 61:748-760

21. Kong A, Gudbjartsson DF, Sainz J, Jonsdottir GM, Gudjonsson SA, Richardson B, Sigurdardottir S, Barnard J, Hallbeck B, Masson G, Shlien A, Palsson ST, Frigge ML, Thorgeirsson TE, Gulcher JR, Stefansson K 2002 A high-resolution recombination map of the human genome. Nat Genet 31:241-247

22. Almasy L, Blangero J 1998 Multipoint quantitative-trait linkage analysis in general pedigrees. Am J Hum Genet 62:1198-1211

23. Hopper JL, Mathews JD 1982 Extensions to multivariate normal models for pedigree analysis. Ann Hum Genet 46:373-383

24. Blangero J, Almasy L 1997 Multipoint oligogenic linkage analysis of quantitative traits. Genet Epidemiol 14:959-964

25. Almasy L, Dyer TD, Blangero J 1997 Bivariate quantitative trait linkage analysis: pleiotropy versus co-incident linkages. Genet Epidemiol 14:953-958

26. Williams JT, Van Eerdewegh P, Almasy L, Blangero J 1999 Joint multipoint linkage analysis of multivariate qualitative and quantitative traits. I. Likelihood formulation and simulation results. Am J Hum Genet 65:1134-1147

27. Lange K 2002 Mathematical and Statistical Methods for Genetic Analysis. Springer, New York

28. Self SG, Liang KY 1987 Asymptotic properties of maximum likelihood estimators and likelihood ratio tests under nonstandard conditions. J Am Stat Assoc 82:605-610

29. Beltinger CP, White PS, Maris JM, Sulman EP, Jensen SJ, LePaslier D, Stallard BJ, Goeddel DV, De Sauvage FJ, Brodeur GM 1996 Physical mapping and genomic structure of the human TNFR2 gene. Genomics 35:94-100

30. Zuchner S, Mersiyanova IV, Muglia M, Bissar-Tadmouri N, Rochelle J, Dadali EL, Zappia M, Nelis E, Patitucci A, Senderek J, Parman Y, Evgrafov O, Jonghe PD, Takahashi Y, Tsuji S, Pericak-Vance MA, Quattrone A, Battaloglu E, Polyakov AV, Timmerman V, Schroder JM, Vance JM 2004 Mutation in the mitochondrial GTPase mitofusin 2 cause Charcot-Marie-Tooth neuropathy type 2 A. Nat Genet 36:449-451

31. Lench NJ, Macadam R, Markham AF 1997 The human gene encoding FKBPrapamycin associated protein (FRAP) maps to chromosome band 1p36.2. Hum Genet 99:547-549

32. Fernandez-Real JM, Vendrell J, Ricart W, Broch M, Gutierrez C, Casamitjana R, Oriola J, Richart C 2000 Polymorphism of the tumor necrosis factor-alpha receptor 2 gene is associated with obesity, leptin levels, and insulin resistance in young subjects and diet-treated type 2 diabetic patients. Diabetes Care 23:831-837

33. Bach D, Pich S, Soriano FX, Vega N, Baumgartner B, Oriola J, Daugaard JR, Lloberas J, Camps M, Zierath JR, Rabasa-Lhoret R, Wallberg-Henriksson H, Laville M, Palacin M, Vidal H, Rivera F, Brand M, Zorzano A 2003 Mitofusin-2 determines mitochondrial network architecture and mitochondrial metabolism. A novel regulatory mechanism altered in obesity. J Biol Chem 278:17190-17197

34. Cota D, Proulx K, Blake Smith KA, Kozma SC, Tomas G, Woods SC, Seeley RJ 2006 Hypothalamic mTOR signaling regulated food intake. Science 312:927-930

35. Deng HW, Deng H, Liu YJ, Liu YZ, Xu FH, Shen H, Conway T, Li JL, Huang QY, Davies KM, Recker RR 2002 A genomewide linkage scan for quantitative trait loci for obesity phenotypes. Am J Hum Genet 70:1138-1151

36. Liu YJ, Xu FH, Shen H, Liu YZ, Deng HY, Zhao LJ, Huang QY, Dvornyk V, Conway T, Davies KM, Li JL, Recker RR, Deng HW 2004 A follow up linkage study for quantitative trait loci contributing to obesity-related phenotypes. J Clin Endocrinol Metab 89:875-882

37. Yang YS, Song HD, Shi WJ, Hu RM, Han ZG, Chen JL 2002 Chromosome localization analysis of genes strongly expressed in human visceral adipose tissue. Endocrine 18:57-66

38. Cai G, Cole SA, Freeland-Graves JH, MacCluer JW, Blangero J, Comuzzie AG 2004 Principal component fro metabolic syndrome risk maps to chromosome $4 p$ in Mexican-Americans: the San Antonio Family Heart Study. Hum Biol 76:651665

39. Pausova Z, Gaudet D, Gossard F, Bernard M, Kaldunski ML, Jomphe M, Tremblay J, Hudson TJ, Bouchard G, Kotchen TA, Cowley AW, Hamet P 2005 Genome-wide scan for linkage to obesity-associated hypertension in French-Canadians. Hypertension 46:1280-1285

40. Gorlova OY, Amos CI, Wang NW, Shete S, Turner ST, Boerwinkle E 2003 Genetic linkage and imprinting effects on body mass index in children and young adults. Eur J Hum Genet 11:425-432

41. Ha AM, Farooqi IS, O'Rahilly S, Stadler DD, Rosenfeld RG, Pratt KL, LaFranchi SH, Purnell JQ 2003 Serum ghrelin levels are inversely correlated with body mass index, age and insulin concentrations in normal children and are markedly increased in Prader-Willi syndrome. J Clin Endocrinol Metab 88:174-178

42. Whatmore AJ, Hall CM, Jones J, Westwood M, Clayton PE 2003 Ghrelin concentrations in healthy children and adolescents. Clin Endocrinol (Oxf) 59:649-654

43. Bacha F, Arslanian SA 2006 Ghrelin and peptide YY in youth: are there race-related differences? J Clin Endocrinol Metab 91:3117-3122

44. Bunt JC, Salbe AD, Tschop MH, Delparigi A, Daychild P, Tataranni PA 2003 Crosssectional and prospective relationships of fasting ghrelin plasma concentrations with anthropometric measures in Pima Indian children. J Clin Endocrinol Metab 88:3756-3761

45. Tschop M, Weyer C, Tataranni PA, Devanarayan V, Ravussin E, Heiman ML 2001 Circulating ghrelin levels are decreased in human obesity. Diabetes 50:707-709

46. Holt RI, Simpson GH, Sönksen PH 2003 The role of the growth hormone-insulinlike growth factor axis in glucose homeostasis. Diabet Med 20:3-15 
47. Murphy LJ 2003 The role of the insulin-like growth factors and their binding proteins in glucose homeostasis. Exp Diabesity Res 4:213-224

48. Kelley KM, Oh Y, Gargosky SE, Gucev Z, Matsumoto T, Hwa V, Ng L, Simpson DM, Rosenfeld RG 1996 Insulin-like growth factor-binding proteins (IGFBPs) and their regulatory dynamics. Int J Biochem Cell Biol 28:619-637

49. Bellone S, Rapa A, Vivenza D, Castellino N, Petri A, Bellone J, Me E, Broglio F, Prodam F, Ghigo E, Bona G 2002 Circulating ghrelin levels as function of gender, pubertal status and adiposity in childhood. J Endocrinol Invest 25:RC13$\mathrm{RC} 15$

50. Malik IA, English PJ, Ghatei MA, Bloom SR, MacFarlane IA, Wilding JP 2004 The relationship of ghrelin to biochemical and anthropometric markers of adult growth hormone deficiency. Clin Endocrinol (Oxf) 60:137-141
51. Dall R, Kanaley J, Hansen TK, Moller N, Christiansen JS, Hosoda H, Kangawa K, Jorgensen JO 2002 Plasma ghrelin levels during exercise in healthy subjects and in growth hormone-deficient patients. Eur J Endocrinol 147:65-70

52. Akamizu T, Muruyama T, Teramukai S, Miura K, Bando I, Irako T, Iwakurai H, Ariyasui H, Hosodai H, Tada H, Matsuyama A, Kojima S, Wada T, Wakatsuki Y, Matsubayashi K, Kawakita T, Shimizu A, Fukushima M, Yojode M, Kangawa K 2006 Plasma ghrelin levels in healthy elderly volunteers: the levels of acylated ghrelin in elderly females correlated positively with serum IGF1 levels and bowel movement frequency and negatively with systolic blood pressure. J Endocrinol 188:333-344

53. Poykko SM, Ukkola O, Kauma H, Kellokoski E, Horkko S, Kesaniemi YA 2005 The negative association between plasma ghrelin and IGF-1 is modified by obesity, insulin resistance and type 2 diabetes. Diabetologia 48:309-316

\section{Erratum}

In the article, "Prenatal Pesticide and PCB Exposures and Birth Outcomes" by Mary S. Wolff et al. (Pediatr Res 61:243-250), the authors report that the legend for the $x$ axis in each panel of Fig. 2 should be (left to right):

BMI $\geq$ median, Weight-gain $\geq$ median

BMI $<$ median, Weight-gain $\geq$ median

BMI $\geq$ median, Weight-gain $<$ median

BMI $<$ median, Weight-gain $<$ median. 